\title{
10
}

\section{Family Policies Across the Globe}

\author{
Fernando Filgueira and Cecilia Rossel
}

Family policies encompass actions aimed at supporting families and regulating family life. In a broad sense, policies that affect family life and that can support families can and do cover many areas of public policy. ${ }^{1}$ We focus here on three main areas of family policy: income support for families with children, early childhood education and care (ECEC) and maternity, paternity and parental leave (see Chapter 2 by Daly in this volume). We zero in on family policies that seek to support families especially during the first years after childbirth. In addition, and more recently, some of these policies also aim to modify private family relationships and, more specifically, how maternity and paternity are lived by societies (Lewis, 1992; Saraceno, 2018; Thévenon, 2011). Despite this general orientation, the way and extent to which different countries have followed these goals varies significantly across

\footnotetext{
${ }^{1}$ Many policies that are not meant to address explicitly family issues can a do have provisions that affect families. Policies in education (for example providing meal services and extending the length of the school day), health (i.e. suppressing co-payment in maternal and early childhood health checkups and interventions), housing (preference in provision of public housing or special interests rates in housing credit aimed at families with children), and even macroeconomic policies (joint or separate taxation schemes) affect family life.
}

\section{F. Filgueira}

Facultad de Ciencias Sociales, Universidad de la República, Montevideo, Uruguay

C. Rossel (凶)

Universidad Católica del Uruguay, Montevideo, Uruguay

e-mail: cecilia.rossel@ucu.edu.uy 
countries and regions in the world. In particular, issues such as coverage and quality, but also design and context of implementation vary significantly. Moreover, countries with very similar development levels might present very different patterns in terms of fiscal efforts regarding family allowances, work leaves, and child care services.

We analyze family policies across the globe, describing patterns in the development of family allowances, leave schemes, and ECEC services both in developed and developing regions. To guarantee fair comparisons between regions, whenever possible our analysis is based on the OECD family database and the ILO global social protection database. However, we also provide further insights using regional data sets and literature focusing on the analysis of family policies in different regions.

Both the literature stemming from the economics of families (Becker, 1981) as well as the literature inspired in the idea of a needs-based/culturally led second demographic transition (Lesthaeghe, 2010; van de Kaa, 2001) posit that as countries develop and enter the post-industrial economy, the sharp divide between the roles of men and women and the traditional nuclear married family should give way to a more fragmented and unstable family landscape and to dual earner households. In addition, such changes should push fertility rates later in calendar and below replacement levels.

Regarding developing countries, this literature would predict a movement toward replacement level fertility and an expansion of the nuclear male breadwinner family. This is due to the changing role, power and preferences of women and to the decreasing efficiency and required functions of extended households in industrial societies, for instance because the state extends polices to support the economic autonomy of the elderly population. If cultural trends continue to move toward more secular and individual self- realization, and if the educational level and labor market involvement of women grows and their control over reproductive choice is secured, these theories would predict a decline in "doing family" (i.e. later nuptiality, increased divorce rates, later and lower fertility, or even childishness). While moderately accurate in the past, these theories are increasingly confronted with empirical trends that make such claims problematic, since the new equilibrium seems to vary quite importantly by region and welfare regime type. While some European countries present close to replacement level fertility and have also seen a recent diminishing rate of divorce and moderate expansion of nuptiality, in the industrialized countries of East Asia fertility rates are at the low/low frontier or below and childless women have increased markedly. In sum, while some regions seem to move to the limit of "undoing" family others seem to remain rather robust at such practice. 
Latin America high income countries show a sharp decrease in fertility but one that is slow to converge across social classes suggesting an increasing bipolar pattern in reproduction and one that does not fit easily with either theory. While the very low fertility of the upper middle classes could follow from Becker-type and second demographic transition arguments, the persistence of high and especially early fertility among low income families together with their highly unstable and fragmented nature is problematic. Also contrary to theory, the region shows highly informal family arrangements and increasing instability and fragmentation in the types of families across all social classes.

Partly what is missing in the theories predicting such outcomes is the importance of family policies and how such policies might lead to very different "equilibriums" regarding family types, nuptiality and divortiality, fertility and the role of men and women within. While this chapter makes no attempt to solve this puzzle, it does provide a wide comparative descriptive assessment of family policies as a first step tackle some of such empirical trends and puzzles.

In the next section we focus on the demographic changes in family structures and its relationship with different configurations in state policies toward families with small children. Then, the main features of the European experience in family policies are presented. The following sections describe the development of family allowances, work leaves, and ECEC services in other regions of the world-both developed and developing-comparing them to the European countries. The final section presents concluding remarks regarding the main challenges related to the consolidation of these policies across the globe.

\section{Demographic Stages, Economic Development, and Family Policy}

Fertility rates have been dropping consistently around the world for the last 25 years. With the exception of the most developed countries (European Union) where fertility has slightly bounced back after hitting their lowest mark by the end of the twentieth century, the middle income and upper middle-income countries of the developing world are converging toward replacement level fertility (Fig. 10.1).

This, combined with an aging population (which implies less women in fertile ages and more elderly in the total population) will translate into a lower proportion of children and teenagers. Except for sub-Saharan Africa, where 


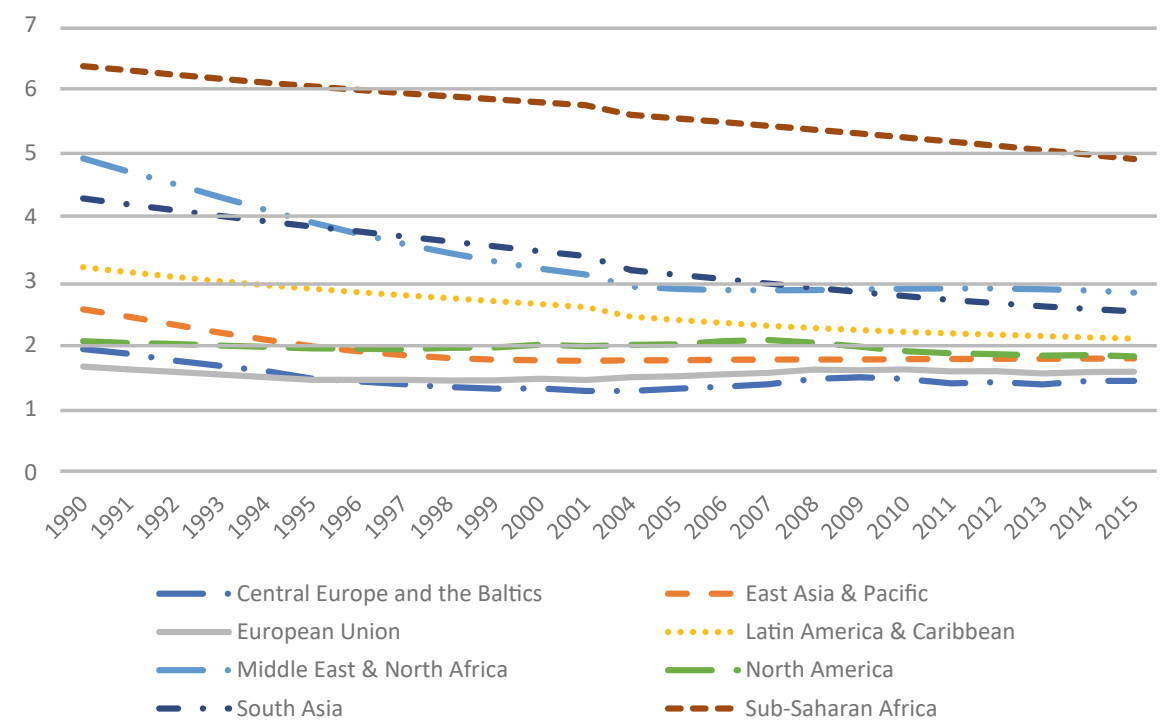

Fig. 10.1 Evolution of fertility rates by region, 1992-2015 (Source Prepared by the authors based on World Bank Open Data, updated 2016. Regions in the figure follow the definition of the World Bank Open Data Bank)

the population is still very young and aging has not advanced, the proportion of children has dropped quite dramatically and will continue do so in almost all regions.

Overall, it can be stated without much doubt that, as emerging and developing countries grow, fertility rates will continue to decline, the proportion of elderly will continue to increase and the proportion of children in the overall population will decrease (up until a certain point). Dependency ratios will also decrease in most regions of the world. This opens a window of demographic opportunity, since there is room for more social and economic investment in smaller child cohorts when fertility drops and the elderly are not yet a larger share of the population. Thus, similar levels of overall spending in children could imply quite different per-capita spending. Furthermore, since overall dependency ratios will go down, there should be economic and fiscal space to further increase spending per-child.

It is good news that the "window of demographic opportunity" will be opened for decades in countries that is behind in the aging process and in the reduction of fertility rates. However, the correlation between overall social spending and child social spending is markedly weaker. Child spending seems to be quite low in regions undergoing such stages of the demographic transition. Overall social protection spending does increase with higher GDP, but that is mainly due to elderly spending rather than spending on children. 


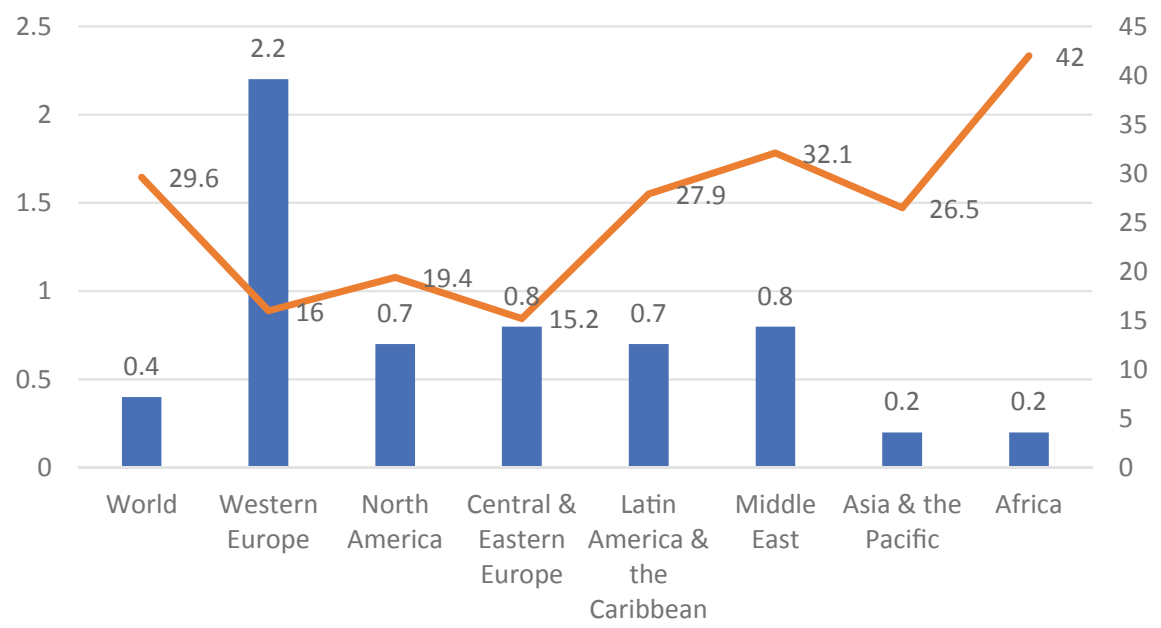

Public social protection expenditure for children (excluding health)

Share of children 0-14 in total population

Fig. 10.2 Public expenditure on child benefits by region, and proportion of children aged 0-14 in total population, 2010/11 (percentage of GDP) (Source Prepared by the authors based on International Labour Organization [ILO], World Social Protection Report 2014/15 Building economic recovery, inclusive development and social justice, Geneva, ILO, p. 14)

In fact, while Western Europe does show a strong positive difference in terms of children's spending even when their proportion of children is low, in the rest of the world's regions spending seems to have either no relation with the proportion of children, or even be inversely-related (Fig. 10.2) (Filgueira \& Rossel, 2017).

Such a pattern is highly problematic. Poorer countries systematically under-invest in children's welfare and in doing so they risk losing the possibility of harvesting the demographic bonus during the window of opportunity that will come when they lower their fertility rates, since their adult cohorts will be less productive than if investment had been robust during their childhood years. Furthermore, since poorer countries are also on average highly unequal it is quite likely that such under-investment in family policies will lead to weaker and less efficient forms of family arrangements in lower income groups since the material basis for stable partnerships will be lacking, ${ }^{2}$ thus, missing on the gains that could come from such cooperation among men and women or in same sex marriages and partnerships.

\footnotetext{
${ }^{2}$ Lower income families and in general lower income people show earlier entry into marriage or union, and childbearing and lower stability in family arrangements, thus increasing lone parent households.
} 


\section{Family Policy in Europe}

Although with significant variations between countries, Europe is the most demographically advanced region, with low fertility rates and an aging population, as well as with high female labor force participation rates (for more details see Chapter 9 by Adema, Clarke, \& Thévenon in this volume).

The fiscal effort on family policy in Europe varies both in magnitude and composition. While the Nordic countries, France, Great Britain, and some Eastern European countries report levels of spending are above 3\% of GDP, southern Mediterranean countries show levels below 2\% of GDP. Composition also varies among high spenders. Nordic countries systematically show high spending in childcare services, while others such as Ireland and the UK focus more on cash transfers. In some countries-as in France and Germany-tax breaks are also quite important (Adema, Clarke, \& Thévenon in this volume)

Family allowances, tax credits, and other forms of cash transfers to families with children constitute a major part of the European system of social protection for children and families. All countries in Europe have some form of family allowance anchored in national legislation (ILO, 2014). Eligibility for the most part is wide, either through social insurance mechanisms or through universal non-contributory systems. In many countries in addition to social security or even universal benefits additional targeted benefits for poor, needy, and single parent—usually female-headed families are in place.

Maternity leaves have been in place in Europe for a long time and they are usually linked to social insurance schemes (ILO, 2014). Leave designs vary in terms of duration, type of benefit, flexibility, entitlement and conditions for returning to work. In the Nordic countries (like Norway or Sweden) the trend has been toward relatively short maternity leaves combined with relatively long parental leave (Allewell \& Pull, 2003; Bruning \& Plantenga, 1999; OECD, 2011). The possibility for both parents to use leave and the establishment of "daddy quotas" which can only be used by fathers are important features in the Nordic design of leaves (Moss \& O’Brien, 2006; Ray, Gornick, \& Schmitt, 2008; Adema, Clarke, \& Thévenon in this volume).

Early childhood care services are quite developed in large parts of Europe. The leaders in terms of coverage and quality, both historically and today, are the Northern European countries, especially the Nordic countries (around $50 \%$ or more, with the exception of Finland), though coverage rates for 0-2 years old are also very high in France (Fig. 10.3). Among the Southern Mediterranean countries, while Portugal and Spain were laggards in the 


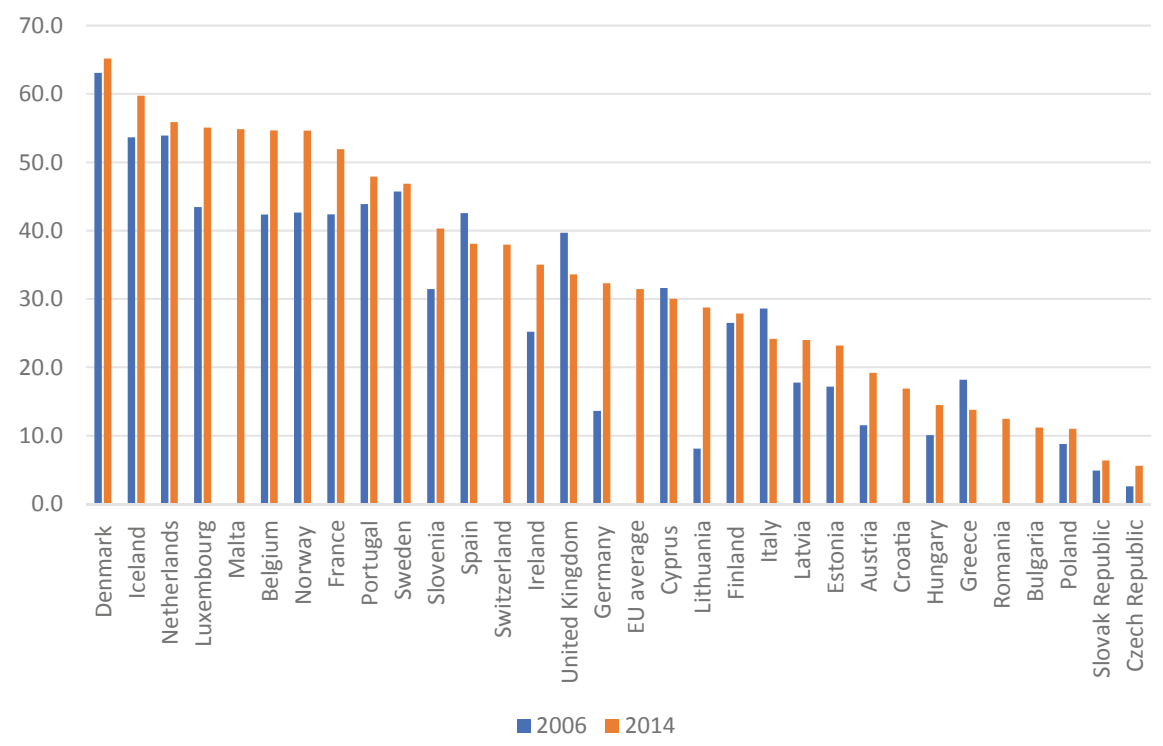

Fig. 10.3 Europe: Participation rates in childcare and pre-school services for 0-to-2year-olds, around 2006 and 2014 (Source Prepared by the authors based on OECD family database Chart PF3.2.A)

early 1990s they have caught up and show coverage rates above the European Union (EU) average in the 2000s. Greece, Italy, and many Eastern European countries show the lowest coverage rates. Denmark, Iceland, and Norway, together with Malta and Luxembourg also report smaller gaps in their coverage rates according to socioeconomic level (OECD, 2019b). In contrast, despite the high average rates of coverage in Belgium, the Netherlands, and France the differences in coverage between the lowest tercile and highest tercile are stark. This is also the case in some low coverage countries, though in others coverage is low across socioeconomic levels (OECD, 2019b). Regarding children at older ages—typically between 3 and 4 years to 5 years old-coverage has become almost universal in most Western and Eastern European countries, going from an average gross enrolment ratio of $75 \%$ to more than $90 \%$ (OECD, 2019b).

Still, the variations in Europe in the three different policies that have been depicted have clear implications in terms of child poverty and how such rates compare to those of the general population. The Nordic countries present generous and universal family allowances-in addition to other cash transfers for vulnerable families, by far the most developed systems of family (maternity, parental and paternity) leaves and widely available ECEC systems 
(Finland is the exception in use, though not in availability ${ }^{3}$ ). The result is the lowest rates of child poverty, and usually rates that are below to those of the general population (OECD, 2019a).

In contrast, Southern Mediterranean countries have weak family and child protection systems. Their weaknesses are not homogeneous. For example, Portugal has a rather robust leave system in design, yet informality makes coverage weaker. Spain has developed in the last years an extended ECEC system, but has one of the least generous family allowance systems in Europe. Greece, despite the recent expansion of leaves, remains low in most of the other policy arenas. Italy is a below average performer in the three policy arenas considered here. Child poverty is among the highest in Europe, and is always above the poverty rates of the total population.

\section{Family Policy in Other Developed Regions}

\section{North America (Canada and the US)}

The United States and Canada present rather different demographic profiles. The US remains a young nation among developed ones and has relatively high fertility rates (Total Fertility Rate [TFR] 1.76 in 2017, World Bank, 2020a) and medium labor force participation rates by women aged 15-64 (55.7\% in 2019, World Bank, 2020b). Canada presents significantly lower fertility rates (TFR 1.49 in 2017, World Bank, 2020a) and higher female labor participation (60.65\% in 2019, World Bank, 2020b).

These two countries have very different profiles in terms of fiscal efforts and policies on families and children. The US presents one of the lowest fiscal efforts compared to other OECD countries regarding public expenditure (1.2\% of GDP) and a large part of that effort comes in the form of tax breaks, not direct cash (Fig. 10.4). Yet, the US presents wide variation in terms of family policy at the state level (see Chapter 18 by Parolin \& Daiger von Gleichen, and Chapter 17 by Engeman in this volume). Canada's effort is not much higher, but a large part of such effort is directed toward cash transfers in the form of family allowances and maternal and parental leaves.

Most of the US's cash transfers to families with children come in the form of tax breaks or special cash transfers for needy or poor families. While the system in Canada is also means-tested on family income, its coverage is quite large and it is far more generous than in the United States. The US does

${ }^{3}$ This is partly explained by the extremely generous leave scheme in Finland where the combination of benefits maternal, paternal and parental) allows for almost two years of total leave after birth. 


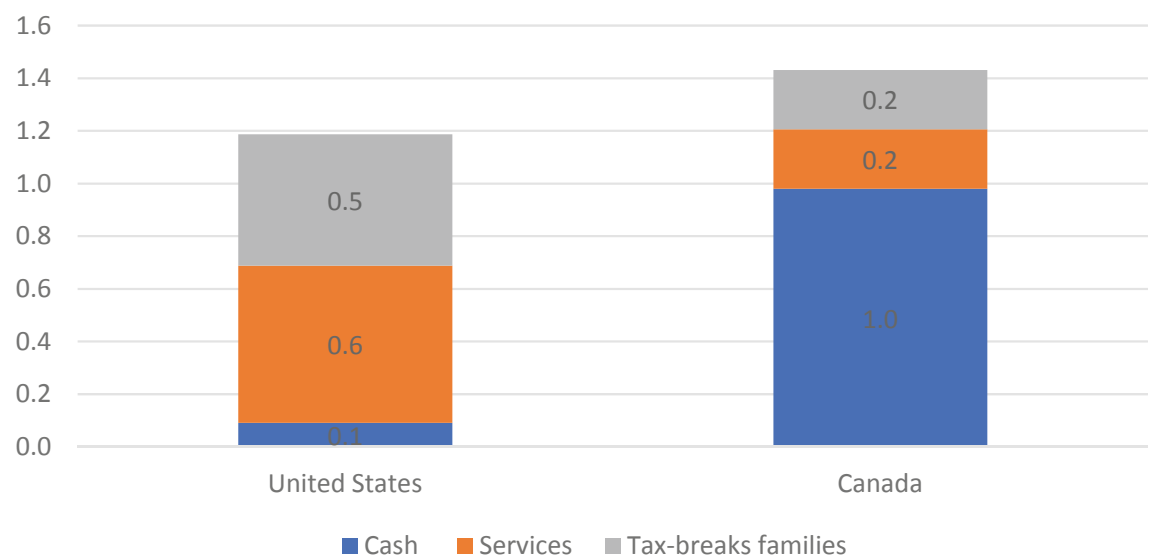

Fig. 10.4 CANADA AND UNITED STATES: Public expenditure on family benefits by type of expenditure, in per cent of GDP, around 2013 (Source Prepared by the authors based on OECD Family Database, Chart PF1.1.A. Public spending on family benefits)

not have a family allowance system, while Canada has a well-developed one. ${ }^{4}$ Also, the US stands out as one of the few countries in the world with no national legislation defining a mandatory paid maternity leave or parental leaves, although the federal law guarantees job protection for 12 weeks of unpaid maternity leave. Yet even such a narrow entitlement is hollowed out by the exemption for employers with less than 50 employees to comply with the norm. Canada has had maternity leaves anchored in social security starting in the 1970s, and during the nineties has introduced and increased parental leave scheme (from paid maternity leave for 17 weeks in 199052 weeks of potential paid maternity leave including both maternity and parental leaves

\footnotetext{
${ }^{4}$ Created in 1944 with the family allowances act, the Canadian system continues to reflect its origin as a universal family allowance program, with subsequent modifications to provide more adequate and targeted benefits for low income families. These changes have resulted in an increase in benefits for families with moderate income and a reduction or ending of benefits to higher income families. The US program was passed quite later and enacted as the Earned Income Tax Credit (EITC), which was part of the Tax Reduction Act of 1975. The credit was designed to help the working poor-families with income below the poverty level despite having working family members. It was initially authorized for only one year. However, the Revenue Adjustment Act of 1975 extended the EITC through the 1976 tax year. This seemed to set a precedent and each year the credit became a part of tax provisions that extended its authorization. It wasn't until the Revenue Act of 1978 that the credit became permanent. In 1986, the Tax Reform Act indexed the credit amount and the phase out levels for inflation. The US program has remained true to its origin, mainly as a tax break or credit targeted at the poor population. One of the disadvantages of this reliance on yearly tax breaks rather than monthly payments is that families living close or under the poverty line enter and exit such a situation throughout the year not on a yearly basis. Thus a monthly payment constitutes an income floor better adapted to the fluctuations in the vulnerability of families that is better fitted to the real life of families.
} 
in 2016). In real terms, replacement rates for maternity leave and parental leaves hover around $50 \%$ of past earnings on average.

The United States $(0.6 \%$ of GDP) and Canada ( $0.2 \%$ of GDP) have relatively low public spending in ECEC. Private services and informal care dominate the childcare sector in these countries, and the early education sector is confined to preprimary schooling for children 5-6 years. The negative consequences of this weak investment by the public authorities can be seen clearly in the services on offer, in particular, high costs to parents leading to unequal access and the segregation of children according to income. Low investment defeats a major purpose of these services and leads inevitably to low quality of services, lack of sustainability, and child care shortages. Unavailability of services also raises barriers against women's full-time employment and channels women toward low-paid, part-time jobs (Immervoll \& Barber, 2006).

Free of charge or subsidized ECEC is not widely available and show variation between states and provinces. Coverage is among the lowest across OECD countries, though not as low as could be expected given its low fiscal effort. Still they are below the EU average. According to UNESCO data, gross enrolment rates in the US for preprimary school children aged 3-5 barely reach $70 \%$ and in Canada are below $75 \%$. The average for developed nations is close to $87 \%$.

In sum, Canada and the US are different, but both share rather underdeveloped systems of ECEC. In terms of family allowances and leave policies, Canada outperforms the US clearly, even though the fiscal effort of Canada in terms of cash benefits remains one half percentage point below the EU average as a proportion of GDP. Poverty levels are thus different, but both countries present child poverty rates above the OECD average and higher child poverty than poverty in the general population.

\section{Oceania (Australia and New Zealand)}

In demographic terms, Australia and New Zealand are advanced nations. Despite having mostly finished their first demographic transition, they have never reached the lowest-low fertility scenarios that can be seen in many European countries. The TFR in Australia hover around 1.8 for the latest years, while the TFR in New Zealand reaches lows of 1.8 and highs of 2.2, quite above replacement rates. The average TFR for the EU is 1.5. Likewise, while aging is a clear trend, they remain relatively "young" compared to other countries of similar GDP per-capita. Women's labor force participation rates are high, and in many cases higher than European countries. 


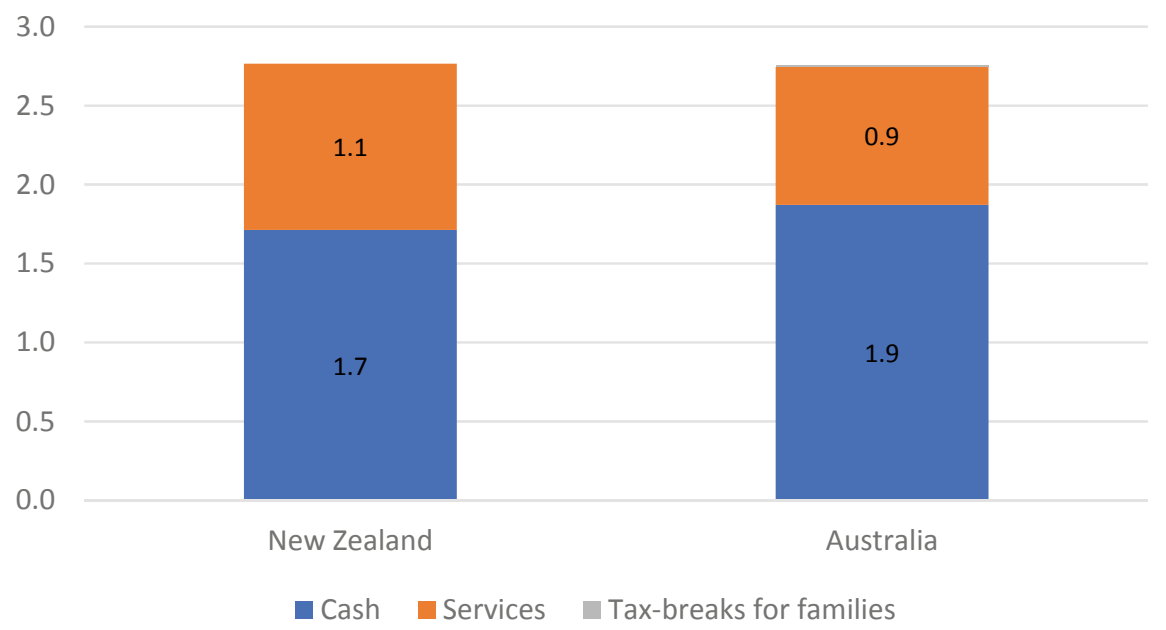

Fig. 10.5 OCEANIA (OECD): Public expenditure on family benefits by type of expenditure, percentage of GDP, around 2013 (Source Prepared by the authors based on OECD Family Database, Chart PF1.1.A. Public spending on family benefits)

Both Australia and New Zealand present relatively high levels of spending on child benefits concentrated on direct cash transfer and to a lesser extent services, while tax breaks for families with children are non-existent (Fig. 10.5).

Both countries have systems of family allowances that were inspired by principles of universality, ${ }^{5}$ but subsequently became means-tested to increase payments for lower income families. However, they remain high coverage systems that neither rely on narrow definitions of need, nor on contributory formal employment. In Australia, almost all families with children can access family allowance and additional payments for child support.

In the case of Australia, even though cash benefits are named as tax credits, they are given as direct monthly payment or as a yearly lump sum. ${ }^{6}$ In the case of New Zealand, targeting is somewhat more stringent and coverage seems to be a contested issue, as the failed attempt in 2014 to make benefits flat rate and universal demonstrates.

Consistent with their liberal tradition, Australia and New Zealand did not have systems of maternity leaves well into the twentieth century. As in the US, these countries had some form of non-paid maternity leave, but it was

\footnotetext{
${ }^{5}$ In the case of New Zealand, it was originally means-tested but as early as the 1940 s it was reformed as a universal system.

${ }^{6}$ This form of providing benefits solves the problem of low income families losing eligibility, since tax records and tax abatement are not possible or more complicated to achieve among this population.
} 
only in the late twentieth century and early twenty-first century that they developed paid maternity and parental leaves. Australia would only introduce paid maternity and parental leaves in the year 2011 with a total length of 18 weeks. New Zealand did it somewhat earlier, in 2003, allowing for 12 weeks of maternity leave. They would increase the length of paid maternity leave from that year onwards reaching a total of 18 weeks by 2016. No paid parental or paternity leaves are available in New Zealand while Australia introduced two weeks of paid paternity leave as an optional quota of parental leaves by 2013. Both countries have around 40 weeks of non-paid but job protected parental leaves.

The replacement rates vary by income level. For mothers_or fathers in the case of Australia — with earnings that are half of average earnings, replacement is slightly below full replacement, but as income goes up replacement level drop to less than $50 \%$ of past earnings.

There is no data on take up of leaves provided by the OECD, but the wide coverage in social security implies wide access to such benefits. According to a recent report (Growing Up in New Zealand, 2014) as many as $84 \%$ of mothers took a combination of paid maternity, non-paid maternity, and annual paid leave at the time of birth. Yet it is true that quite low replacement rates might make upper income women less likely to take such leaves.

ECEC have a relatively more recent development in Australia and New Zealand than most of Europe, but in contrast to the US and Canada, fiscal efforts are more robust. When looking at overall coverage at very early ages (0-2 years old) there is a clear upward trend since the 1990s, reaching and overall coverage of more than $40 \%$ in New Zealand and around $30 \%$ in Australia (Fig. 10.6).

Coverage in preprimary school in Oceania is high with almost universal coverage for 4 and 5 year-olds, but not for those aged three. For the latter group, coverage is relatively high in New Zealand, but rather low in Australia.

In sum, Oceania presents an intermediate position regarding child and family policies when compared with Europe and the North American countries. While laggards in ECEC and leave policies, and with relatively narrow coverage in ECEC and limited extension in leaves, they have a strong, almost universal family allowance system that is also quite generous (more so in Australia than New Zealand). The impact on child poverty and overall inequality is positive, making them countries with average levels of poverty when compared to other similarly developed countries, and levels that are either similar or slightly higher than those of the general population. 


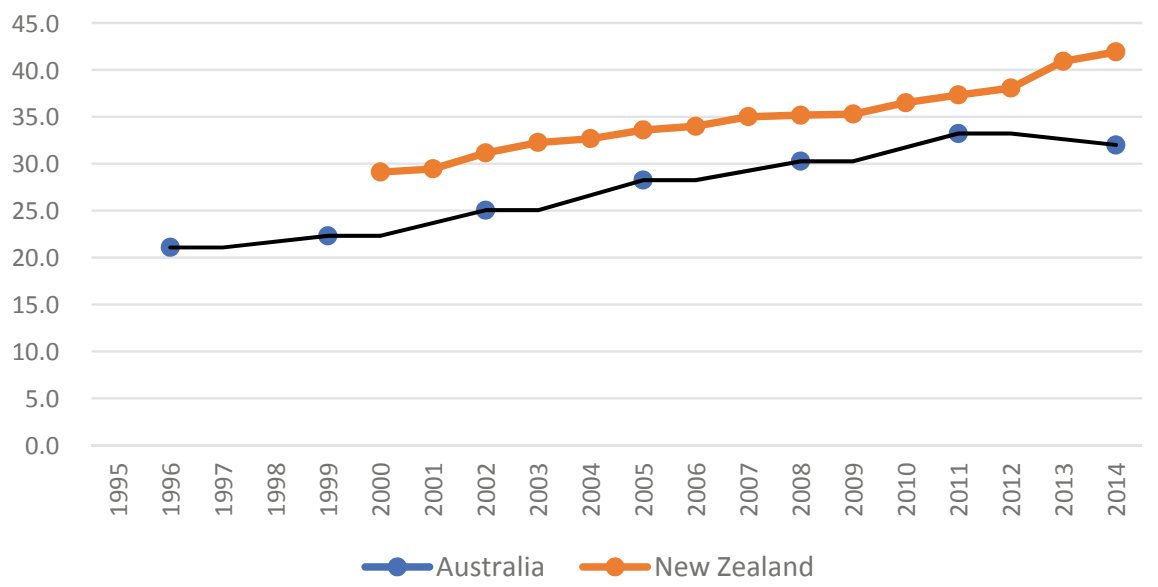

Fig. 10.6 OCEANIA (OECD): Enrollment in child care services (children between 0 and 2 years old), 1995-2014 (Source Prepared by the authors based on OECD Family Database 2017, PF3.2: Enrollment in childcare and pre-school)

\section{Family Policy in Developing Regions}

\section{Asia}

Asian countries are very heterogeneous regarding fertility, dependency rates, and life expectancy. East Asian countries, for example, perform similar to other developing regions, with a relatively low fertility (1.6 children per women in 2010-2015) and an important decline in dependency ratios in the last decades (from 71.7 in 1980 to 41.4 in 2011) (Cecchini, 2014). Some East Asian countries, such as Japan and South Korea have levels of fertility that approach or reach very low levels, with TFR of 1.4 and 1.3 respectively, while China presents a TFR of 1.6 (for the period 2010-2015) (United Nations Department of Economic and Social Affairs, 2015). By contrast, other Asian sub-regions (Southern and Central Asian countries) present fertility rates that are above 2 and in western Asia rates are almost around 3 children per women (United Nations, Department of Economic and Social Affairs, 2015).

Targeted cash benefits are used most often in Asia as instrument of social protection, established largely by central governments. The traditional child/family benefits are not extensively used, however. For example, only one-third of the countries (16 out of 48) provide any kind of child or family allowance, the smallest proportion of all the regions (ILO, 2014).

The two most developed Asian countries with information from the OECD (Korea and Japan) show moderate spending efforts with quite different profiles: strong on child care services in Korea, more concentrated 
on cash transfers in the case of Japan (Fig. 10.7). Still, both of these countries have notoriously increased child and family protection policies in the last years partly as a response to lowest fertility scenarios and limited women's labor force participation.

The existence of family allowances in Asian countries, with the exception of Korea and Japan, is rare. Family allowances are only available in Sri Lanka and payable to the contributing worker rather than to families (Mokomane, 2012), but several countries have adopted other forms of cash transfers targeting families with children. There are, however, important variations across sub-regions. While in Central Asian countries have cash transfers programs with very limited coverage (Gassmann, 2011), several East Asian countries have cash transfers programs targeting families with children, most of them conditioned to school attendance or children's health check-ups. This is the case of Cambodia, Indonesia, and the Philippines (Cecchini, 2014; Kohler, Cali, \& Stirbu, 2009). In 2012, Indonesia's CCT, Program Keluarga Hatapan (PKH), was covering around 1.5 million households (around $2.5 \%$ of the country's total households), while the Philipinian CCT, Pantawid Pilipino Program, was covering 3 million households (around $15 \%$ of total households) (Cecchini, 2014). Evaluations show some of these programs are being effective, among other things, in increasing enrolment among younger children (3-11 years old) and increasing attendance among 6-17 years old (Chaudhury, Friedman, \& Onishi, 2013).

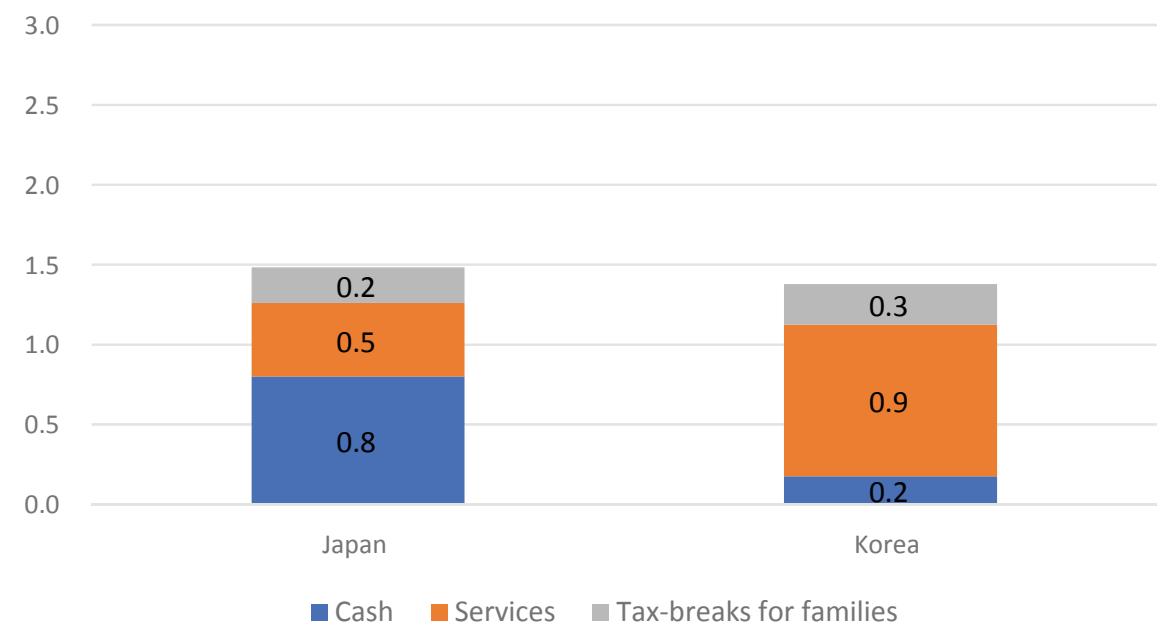

Fig. 10.7 ASIA (OECD): Public expenditure on family benefits by type of expenditure, in per cent of GDP, 2013 (Source Authors' elaboration based on OECD Family Database, Chart PF1.1.A. Public spending on family benefits) 
Although still far from the European parameters, a few Asian countries offer relatively generous maternity leave policies and several countries have maternity leave with a duration according to or near ILO's recommendation. After reforming its system in 2013, Vietnam stands out as the most generous country regarding maternity leave, with 6 months (and the possibility of an extra month if the mother has more than one child) of leave for mother. By contrast, in Bhutan and Maldives there is no maternity leave anchored to national legislation.

Some Asian countries (for example, Korea, Japan, Taiwan) have also introduced parental leave policies for relatively long periods and with some kind of replacement of salaries (Chin, 2012). Considering only Korea and Japan, Korea provides a more generous scheme in salary replacement through maternity leaves, while Japan offers more paid coverage in the parental leave scheme than Korea.

Several Asian countries are developing policies to increase accessibility to childcare services by increasing the number of childcare facilities, as well as increasing the number of children who are eligible for childcare subsidies (Chin, 2012). In Korea, between 2001 and 2015 the proportion of children in those ages that were enrolled in childcare services increased from 3 to $34 \%$, while in Japan it increased from 22\% in 2007 to $30 \%$ in 2014 (OECD, 2019c).

\section{Africa}

African countries have the highest fertility rates in the world, reaching an average of 4.7 children per women, and in some sub-regions (middle Africa, for example) reaching almost 6 children per woman (United Nations, Department of Economic and Social Affairs, 2015).

In the last decades, however, North African countries show a declining trend in fertility, combined with a cultural transformation in marriage and childbearing practices (Roudi-Fahimi \& Mederios Kent, 2007). Also in the last decades, there has been an increase in women's participation in non-agricultural employment (Mokomane, 2012). Despite these trends, in comparative terms African countries are regions where the family-along strong traditional patriarchal lines-is a long-established institution and also the main provider of welfare for individuals in times of crisis or while facing risks such as unemployment, sickness, or old age (Mokomane, 2012).

As in other developing regions, family allowances in Africa are an exception and cash benefits for families have adopted the form of cash transfers to reduce poverty (Adato \& Hoddinott, 2007). There are several cash 
transfer programs in different countries. In some cases, they are conditioned to certain behaviors (such as sending children to school or vaccination). Some examples are Burkina Faso's CCT for Orphans and Vulnerable Children, Ghana's Livelihood Empowerment against Poverty (LEAP), Nigeria’s In Care of the People (COPE), Tanzania's Community-Based CCT (CBCCT), and Senegal's Conditional Cash Transfer for Orphans and Vulnerable Children. The maintenance grant in Namibia, for example, is oriented to guarantee maintenance of children with disabilities and establishes a USD 26 of monthly cash transfer for the first child plus USD 13 per month for every additional child, up to 6 children (Mokomane, 2012). Although some CCTs in Africa are implemented nationally and funded mainly by governments, some CCTs are the result of partnerships between governments and international donors like the World Bank, UNICEF, the Department for International Development (DFID) in the UK, and other governmental and nongovernmental organizations. Also, African CCTs are frequently implemented in regions and relying on community participation (Southern African Social Protection Experts Network, 2016).

Unconditional transfers have a long history in the region and have their roots in the South African pension system introduced in the 1920s to protect basically the minority white population (Mokomane, 2011). Indeed, the earliest unconditional cash programs in Sub-Saharan Africa were old age pensions established in South Africa (1928), Namibia (1949), and Mauritius (1958) (Mokomane, 2012). However, with the exception of Mauritius and South Africa, they do not specifically target families with children (NiñoZarazua, Barrientos, Hulme, \& Hickey, 2010). The most relevant policy here is the South African Child support grant, which has proven to have significant impacts on children's nutrition and height (Agüero, Carter, \& Woolard, 2006, 2007).

Maternity leaves in Africa are mainly of the contributory type (this is, part of the basic social insurance scheme), and apply to a minority of salaried workers (Mokomane, 2012). Therefore, although maternity leave is comprehensively available in most African countries, this benefit applies only to a minority covered by social security as salaried workers. Also, only a few countries adopted ILO's recommended of 14 weeks or more (Mokomane, 2011) (Fig. 10.8).

Only three countries (Mauritius, Uganda, and Tanzania) recognize paternity leave formally. In the rest of the countries, there is either a special multi-purpose leave provision which could potentially be used by fathers as paternity leave (Mokomane, 2011) or no legislation at all. 


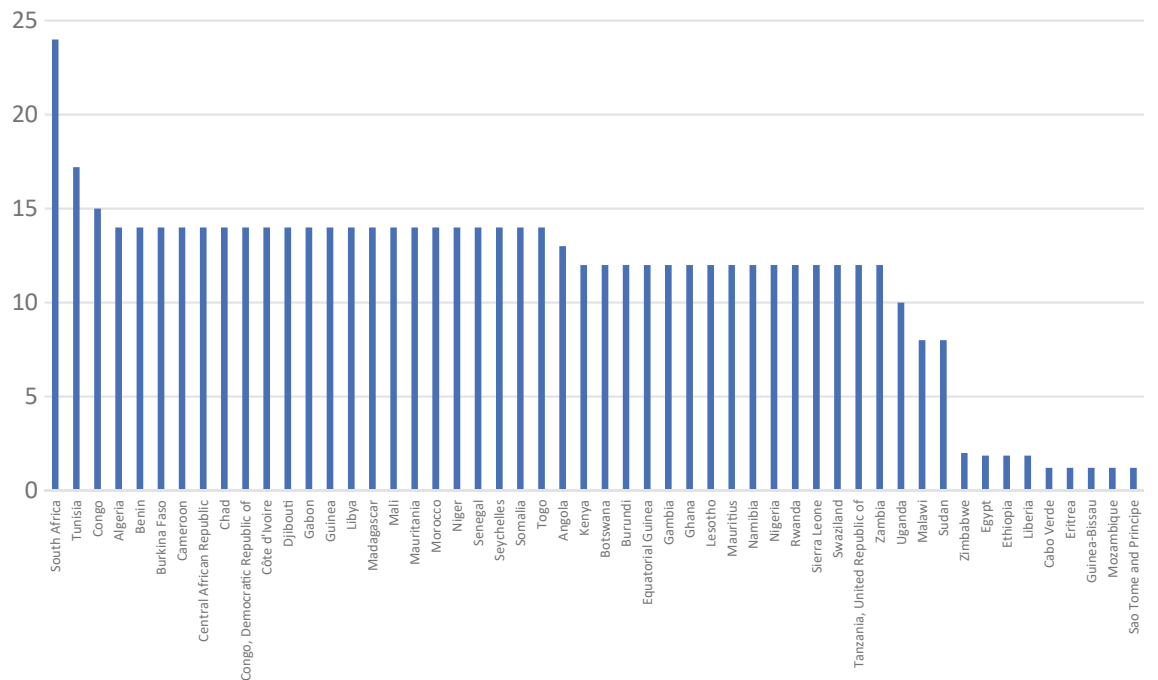

Fig. 10.8 AFRICA (selected countries): Length of maternity leave (in weeks), circa 2014 (Source Prepared by the authors based on International Labour Organization (ILO), World Social Protection Report 2014/15 Building economic recovery, inclusive development and social justice, Geneva, ILO)

\section{Middle East}

In Middle Eastern countries, women's participation in the labor force participation is low and the development of family policy is limited (O'Brien, 2012). In fact, although there is variation across countries, social policy for families has "tended to reflect and reinforce the patriarchal gender contract" (Moghadam, 2005, p. 38).

While in these countries families remain as the key provider for care and economic support, there have been some developments regarding family policies. In the last few decades, several countries have established noncontributory benefits. These are mainly cash transfer programs, some of them targeted to families that have lost their breadwinner or do not have one (e.g. orphans, widows, divorced women, or even women who are single after a certain age). However, there is still relatively low coverage of poor and vulnerable working families with children (Machado, Bilo, Veras Soares, \& Guerreiro Osorio, 2018).

In contrast to what happens in other regions such as Latin America, most cash transfer programs are unconditional and frequently followed by in-kind transfers, such as food distribution and fuel subsidies (Machado et al., 2018) 
Compared to African countries, Middle Eastern countries seem to be more advanced in the development of preprimary education. As shown in Fig. 10.9, enrolment in pre-primary education in some of these countries shows a growth trend.

Although there are no available statistics of enrolment in children under 2 years old, the coverage is expected to be much lower. Also, in several countries, employers are obliged to provide childcare facilities dependent on the number of female employees (O'Brien, 2012).

The development of work-related leaves in the region is still incipient and mostly relying on the benefits offered through public sector employment (Kabeer, Ashwini, \& Ragui, 2019). However, some countries (Egypt and Dubai, for example) have recently introduced changes to their legislation to either reach the minimum international standard or give women working in the private sector the same rights of those enjoyed by public sector employees.

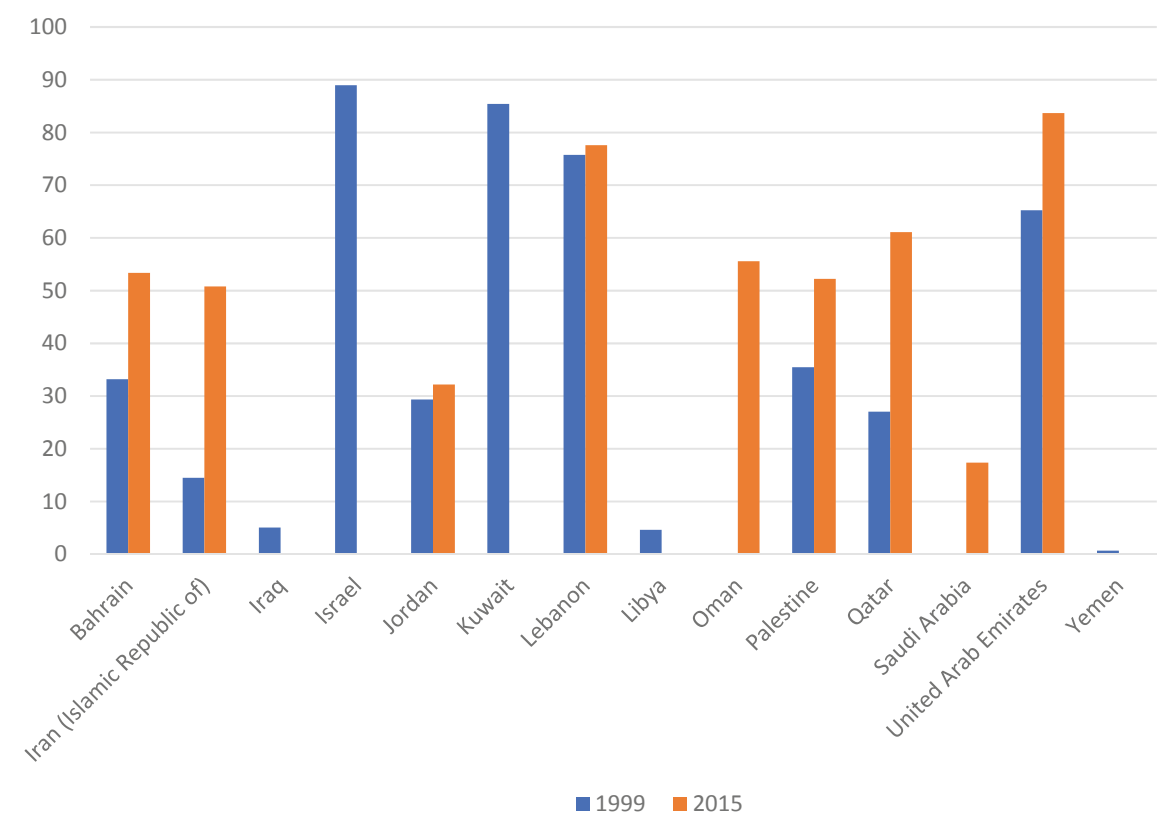

Fig. 10.9 MIDDLE EAST (selected countries): Enrollment in pre-primary education (3-5 years old), 1999 and 2015 (Source Prepared by the authors based on data from UNESCO/UIS) 


\section{Latin America}

Most Latin American countries have experienced a decrease in mortality and fertility rates, as well as an increase in life expectancy. As a result, the region's population is aging and households are becoming smaller. At the same time, changes in divorce and nuptial patterns (with an increase of people living together without being married and a decrease in formal family arrangements) translate directly into changes in the shape of families (Arriagada, 2004; Rico \& Maldonado, 2011).

Also, the region has gone through the massive incorporation of women into the labor market. Increases in women's participation in the labor market contribute to a "care crisis", due to pressures that are being experienced by families and particularly by women because of the combination of paid work outside their homes and demands for care of children and other dependents (Rico, 2011). This crisis is due to the pattern of the unequal distribution of unpaid work between men and women, which are very stratified by socioeconomic variables (CEPAL, 2010; Espejo, Filgueira, \& Rico, 2010).

The only two countries for which comparable OECD data on overall spending on children and family was available, Chile and Mexico present low spending levels in the international landscape. Compared to Mexico, Chile's effort is larger-similar to the cases of low investment in other OECD countries-and balanced between cash transfers and care services. Mexico's effort is lower than almost all other OECD countries. Even spending on cash transfers to children and families with children is quite low, despite the fact that it has one of the largest CCT programs in Latin America.

A recent study carried out at the Economic Commission for Latin America and the Caribbean (ECLAC) (Tromben \& Podestá, 2019) attempts for the first time to apply the OECD methodology to estimate family spending in nine countries in the region, including Chile and Mexico. The results show that the region falls clearly behind OECD levels of spending regarding monetary transfers with an average of $0.4 \%$ of GDP against the OECD average of 1.2 and European Union average of 1.5 (this includes contributory and non-contributory direct transfers, estimated pay on maternity, paternity, and parental leaves and fiscal credits to families with children). Only Argentina reaches levels that are slightly below the OECD average with $1.1 \%$ of GDP. Honduras, Guatemala, Perú, and Costa Rica spend $0.2 \%$ or less of their GDP in these transfers while Chile, México, and the Dominican Republic spend between 0.4 and $0.7 \%$ of their GDP (Tromben \& Podestá, 2019). 
Most of Latin America did not have a system of family allowances such as the ones that in the post war period swept through most of Europe. Exceptions in this sense are Argentina, Uruguay, and Chile, which developed early systems of non-targeted yet contributory family allowances, similar to the systems anchored in social security in Europe. The lower rates of formality implied of course lower coverage rates. Other countries developed some form of contributory family allowance in the second half of the twentieth century, but this was usually restricted to small groups of workers (miners in Bolivia, state employees in Venezuela, and other categories around the region). Colombia presents a particular case where family allowances exist in the formal sector but targeted to low income formal workers with children. Even when some of these systems increased contributory coverage with time, the lack of a strong formal workforce hindered coverage, especially of the poorer sectors of society.

The region would have to wait for the wave of mean-tested conditional cash transfers programs for families with children to really reach part or most of the poor and those working in vulnerable sectors. Some programs are quite stringent and aim at covering the poorest of the poor. But many have moved beyond such narrow coverage and cover today an important proportion of families with children (Fig. 10.10). Most of them have some conditionality attached to eligibility, usually regarding children educational attendance and health check-ups and vaccination.

The value of conditional cash transfers also varies significantly across countries. Looking at the basic benefit for families with children such values go from close to USD 100 per-children to less than USD 20 (monthly transfers) (Cecchini \& Atuesta, 2017). In some countries, such as Ecuador, the value of the benefit is for the whole family and does not increase with number of children. In other countries, such as Uruguay, the values increase at a slower rate by number of children. Most countries have a maximum limit in terms of eligibility for additional child transfers no matter if they have more children. Once they reach the ceiling no additional benefit is granted.

International organizations have played a significant role in promoting the expansion of CCTs in the region (Borges, 2018; Osorio Gonnet, 2019). Although investment in CCTs has grown since 1996 (Cecchini \& Atuesta, 2017), the fact that many CCTs lack support in national laws, or when they have, lack criteria for funding and indexation, makes such systems more volatile than other social protection policies. Even if frequently they have gained legitimacy and have survived government changes, the recent economic downturn seems to be having a clear detrimental effect on the 


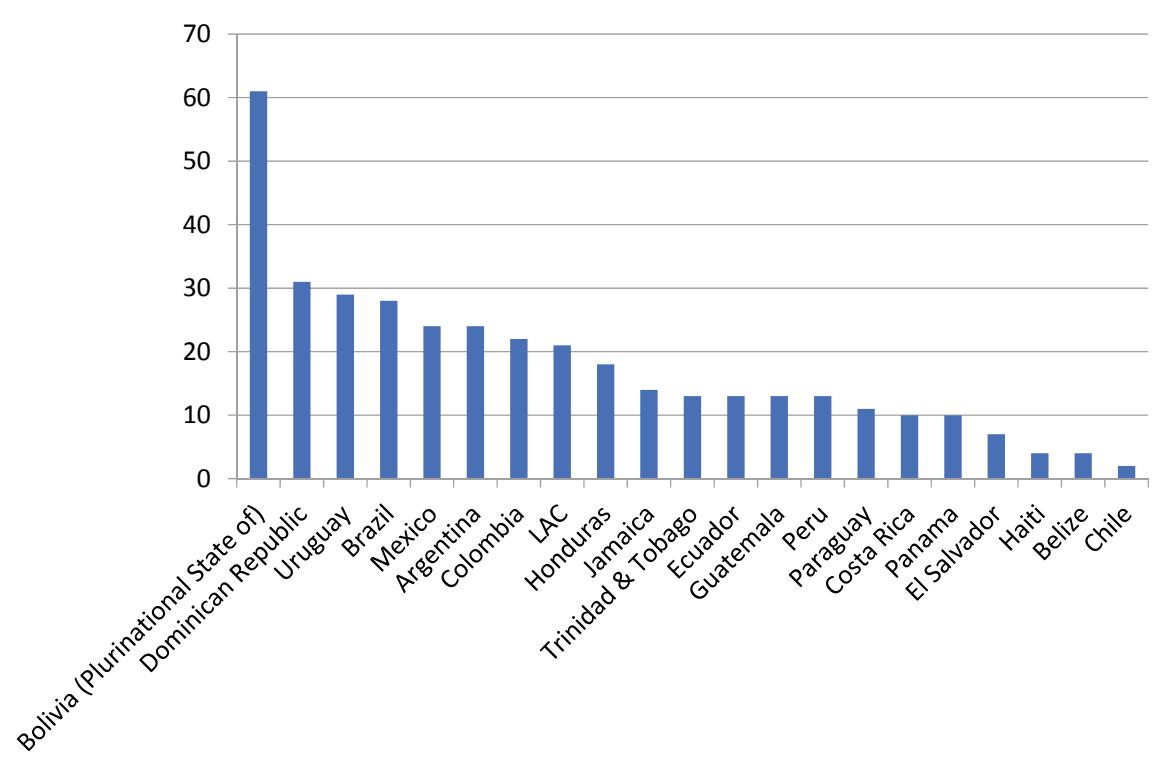

Fig. 10.10 Coverage of individuals in households targeted by CCTs, around 2015. (percentage of total population) (Source Simone Cecchini and Bernardo Atuesta (2017) 'Conditional Cash Transfer Programmes in Latin America and the Caribbean. Coverage and Investment Trends'. Social Policy Series 224. ECLAC)

fiscal priority of these programs in a number of countries. In sum, a question remains around the extent to which these programs are to become a stable feature of a rights-based welfare architecture.

All countries in the region have statutory maternity leave policies. However, there is variation in terms of length and most countries offer less than the 14 weeks established by the ILO. Honduras is probably the most emblematic case, but the Dominican Republic, Bolivia, El Salvador, Guatemala, Haiti, Mexico, and Nicaragua all provide 12 weeks or less. Only nine countries (Panama, Costa Rica, Brazil, Peru, Ecuador, Venezuela, Colombia, Chile and Uruguay) provide 14 weeks or more. Chile is a noteworthy case in the region, with a 24-week maternity leave approved in 2011.

Data on payment rates of maternity leaves is a bit more encouraging: most Latin American countries offer 100\% replacement rates, although in some cases this doesn't necessarily apply to the entire period. But the most important deficit in Latin America's maternity and parental leaves is still basic coverage. In Latin America, maternity leaves are still limited or non-existent for particular sectors, even if formal, like domestic workers, subcontracted, and temporal workers. As a result, the proportion of employed women that 
actually use the maternity leave benefit is relatively low. Furthermore, given the high level of informality and the fact that almost no system includes informal workers most systems of maternity and parental leaves are restricted to a small proportion of working mothers.

Flexibility is another dimension in which Latin America presents limited progress, with scarce options for women on when the leave can be taken or how it can be combined with part-time jobs. An exception to this is Chile where the new post-natal leave allows women to use until 18 weeks and go back to work in a part-time scheme, until the child is 30 weeks old.

Parental leaves are really an exception in Latin America (OIT, ONUMujeres, \& PNUD, 2012; Pautassi \& Rico, 2011). To date, only three countries have parental schemes, included within the maternity leaves. Cuba offers a 9 months' unpaid maternity/paternity leave both to mothers or fathers after the statutory maternity leave. Chile offers mothers with the possibility to transfer the benefit to fathers after the 7 th week after childbirth and for a maximum period of 3 months. In 2013, Uruguay instituted a shareable full paid parental leave that allows either parent to work half-days until the child is six months old (Rossel, Filgueira, \& Rico, 2015).

According to ECLAC, in 2009 Latin America's net enrollment in care services for children between 0 to 3 years old was around 5\% (in Guatemala, Honduras, Dominican Republic, Paraguay) and 20\% (in Cuba and Mexico). The net enrollment rate for children between 3-6 years old was much higher, but only in Cuba and Mexico reaches levels that are near universal. Brazil, Uruguay, Argentina, Peru, Colombia, and Panama present enrollment levels of around 60 and 70\% (CEPAL, 2011; Rossel et al., 2015).

A recent study published by ECLAC shows that enrollment in ages 3-5 has grown significantly in the last decade. In 2014, the average coverage for eight countries was $64.6 \%$. The national coverage of ECEC services for 3-5 years reached $86 \%$ in Uruguay, $79 \%$ in Brazil, $77 \%$ in Chile, $72 \%$ in Mexico, $64 \%$ in Peru, and $61 \%$ in Colombia. Even countries with a very limited coverage in 2009, like Honduras, presented a modest growth in 2014 (37.6\%). Also, enrollment in child care services is highly stratified by socioeconomic level (the high-income population is the one with higher access to services, while lower income sectors present significantly lower attendance rates) and by the urban/rural cleavage (with less coverage in rural areas) (CEPAL, 2017).

The design of child care services in Latin America is quite varied, combining public facilities with private services or services provided by civil society organizations, usually subsidized with state funding (Martínez Bordón \& Soto de la Rosa, 2013; Vegas \& Santibáñez, 2010). In the last decade, 
countries like Mexico, Chile, and Uruguay have expanded child care infrastructure, improving the availability of services for children between 0 and 3 years old (Staab, 2010).

In addition to varying coverage rates, the quality of ECEC services in the region is highly varied. The scarce evidence on the subject suggests a high heterogeneity and persistent precariousness in many countries, concentrated mostly in rural areas and in low socioeconomic contexts (Araujo, López Boo, \& Puyana, 2013; Vegas \& Santibáñez, 2010).

\section{Conclusion}

Compared to pension systems, health care and health insurance, and formal education, family policies are relatively more recent, have a wider variety of institutional settings and usually carry less weight in the fiscal effort of states. Yet it is also true that these policies have grown significantly both in developed as in developing countries.

There are at least two reasons why this trend takes place. First, there is increasing scientific evidence regarding the importance and efficiency of early investment in children promoting their capabilities and protecting them from risks and vulnerability. While children have no vote, knowledge has helped making their case to a larger extent than before. Development will happen through human capabilities and human innovation. And increasingly the scientific community and the policy paradigm are agreeing that the foundation of such capabilities takes place between gestation and the first 4-5 years of life. Still, despite such increasingly positive and strong consensus, the efforts fall short in most cases leaving an important part of small children unprotected. Second, the increasing incorporation of women into the labor market and the relatively frozen landscape regarding male incorporation into domestic chores and care implies that at some point the state would need to enter into the equation organizing services and creating policies that allow for the balancing act of paid and unpaid work that women face day in and day out. Leaves and ECEC are very much led by family changes and demands. In some cases, this takes place without state involvement. Enterprises and markets provide the basis for leaves (through firm-related leave arrangements for families with a newborn) and early childhood care (through private childcare facilities). But such a solution is usually fragmented, insufficient and does not reach the large group of women who cannot access such market solutions, or who are not employed by enterprises granting time of work for family and child care. As shown by Adema, Clarke, and Thévenon in this 
volume (Chapter 9), in the case of OECD countries many of these policies were meant to avoid a very low fertility scenario. In many countries in Eastern Europe as well as in Japan and Korea major hikes to transfers and leaves have taken place with precisely this goal in mind. Despite a major economic malaise affecting the Southern Mediterranean countries, it is possible to see in these countries increasing efforts to strengthen family policies and childcare protection.

The recent experience from the leaders in family policies offers an opportunity for developing regions. Regarding family allowances and cash benefits, European countries have moved toward expanding the coverage but also the generosity of transfers. They have also created specific benefits for loneparents (but see Chapter 13 by Nieuwenhuis \& Madonado in this volume). Regarding work leaves, European countries have expanded both length (way further than the 14 weeks recommended by ILO) and the generosity of paid benefits, sometimes merging maternity and paternity/parental leave schemes. Also, some countries have increased flexibility in leave policies, allowing for more workers to take them and use them for a longer period. "Daddy quotas" have become an increasingly common innovation in European leave systems. Regarding child care services, European countries have significantly expanded coverage both by increasing the number of hours' services are available and the population they are open to (for example, expanding the eligibility criteria to children under 2 years old). They have also installed the importance of encompassing coverage expansion with improvements in service quality, to guarantee that attendance to child care services translate into the expected beneficial outcomes in child development.

Laggards in leaves such as the liberal countries have advanced in creating a modest leave system with the exception of the United States, while they have also moved ahead in coverage and quality in ECEC. Regarding family allowances, the picture is more mixed. Some universal systems have become more targeted (not narrowly, but targeted nonetheless), but in general they have also protected or even increased value. More clear laggards were the Asian developed countries of Korea and Japan. These countries have made major strides in catching up with their western counterparts in ECEC and leaves. The rest of Asia remains underdeveloped in all three policy areas, though some leave systems have advanced and CCT programs do exist in a limited number of countries.

In developing regions, the last 15 years showed major advances in all the areas that we considered throughout this chapter. Monetary transfers to families with children, extended leaves for mothers and larger coverage in many cases, and albeit more modestly, early childhood care and education are part 
of the agenda and in some cases a policy reality. Yet what seems to be lacking in these regions are three critical aspects that are required for sustainability and effectiveness: (1) rarely are these policies based on the idea of a universal set of interrelated transfers and services; (2) overall, the fiscal effort in most of these policies remains modest and the economic downturn of the last years might have a very negative impact on them; (3) the impact of these policies on inequality and poverty so far has remained limited.

Family policy can play-if established generously and of reasonable quality - a major role in increasing social investment for society at large and in decreasing inequality and vulnerability for children and young families. They operate in a critical period where families are most vulnerable and when children are developing their basic cognitive functions. Of course, not all spending in children and families will get the job done. If family allowances and leaves remain limited to formal workers and if ECEC are of bad quality the promise will not be fulfilled. Universal good quality transfers and services are needed, or at least services and transfers that reach both the lower income groups and the middle classes so as to guarantee access to those most in need and reasonable quality.

Developing countries have a long road ahead if they want to transform what today is an embryo of a family and childcare protections system into a full-blown pillar of their social states. Fiscal costs will be important, but the long run benefits in human capabilities, productivity and equality far outweigh the fiscal costs of setting such system up.

Acknowledgment The main contents of the chapter are based on our previous publication Filgueira and Rossel (2017) Social protection for families and early childhood through monetary transfers and care worldwide, prepared for and funded by the Economic Commission for Latin America and the Caribbean Project "Social Protection System and Inequality".

\section{References}

Adato, M., \& Hoddinott, J. (2007). Conditional cash transfer programs: A "magic bullet" for reducing poverty? 2020 vision briefs. Washington, DC: International Food Policy Research Institute.

Agüero, J., Carter, M., \& Woolard, I. (2006). The impact of unconditional cash transfers on nutrition: The South African child support grant. Cape Town, South Africa: Southern Africa Labour and Development Research Unit. 
Agüero, J., Carter, M., \& Woolard, I. (2007). The impact of unconditional cash transfers on nutrition: The South African child support grant. International Poverty Centre (Working Paper Number 39). http://www.ipc-undp.org/pub/IPCWorkin gPaper39.pdf.

Allewell, D., \& Pull, K. (2003). An international comparison and assessment of maternity leave regulation. Comparative Labor Law \& Policy Journal, 22(2/3), 297-326.

Araujo, M. C., López Boo, F., \& Puyana, J. M. (2013). Overview of early childhood development services in Latin America and the Caribbean. Washington, DC: InterAmerican Development Bank.

Arriagada, I. (2004). Cambio de las familias en el marco de las transformaciones globales: necesidad de politicas públicas eficaces. Serie Seminarios y Conferencias, 42. CEPAL.

Becker, G. S. (1981). A treatise on the family. Cambridge, MA: Harvard University Press.

Borges, F. A. (2018). Neoliberalism with a Human Face? Ideology and the Diffusion of Latin America's Conditional Cash Transfers. Comparative Politics, 50(2), 147169.

Bruning, G., \& Plantenga, J. (1999). Parental leave and equal opportunities: Experiences in eight European countries. Journal of European Social Policy, 9(3), 195-209.

Cecchini, S. (2014). Social protection, poverty and inequality: A comparative perspective. Journal of Southeast Asian Economies (JSEAE), 31(1), 18-39.

Cecchini, S., \& Atuesta, B. (2017). Programas de transferencias condicionadas en América Latina y el Caribe: tendencias de cobertura e inversión. Serie Políticas Sociales, División de Desarrollo SOcial, CEPAL.

CEPAL. (2010). Panorama Social de América Latina 2009. CEPAL.

CEPAL. (2011). Panorama Social de América Latina 2010. CEPAL.

CEPAL. (2017). Panorama Social de América Latina 2016. CEPAL.

Chaudhury, N., Friedman, J., \& Onishi, J. (2013). Philippines conditional cash transfer program impact evaluation 2012. World Bank.

Chin, M. (2012). Demographic changes and work family balance policies in East Asia. Good Practices in Family Policy Making. http://www.unav.es/.../b/.../29882_ CHIN_Meeting-May2012.pdf.

Espejo, A., Filgueira, F., \& Rico, N. (2010). Familias latinoamericanas: organización del trabajo no remunerado y de cuidado. Documento de proyecto. CEPAL.

Filgueira, F., \& Rossel, C. (2017). Social protection for families and early childhood through monetary transfers and care worldwide. Paper prepared for the Economic Commission for Latin America and the Caribbean Project "Social Protection System and Inequality".

Gassmann, F. (2011). Protecting vulnerable families in central Asia: Poverty, vulnerability and the impact of the economic crisis. Innocenti (Working Paper, IWP-201105). United Nations Children's Fund (UNICEF). 
ILO. (2014). World Social Protection Report 2014/15 Building economic recovery, inclusive development and social justice. ILO.

Immervoll, H., \& Barber, D. (2006). Can parents afford to work? Childcare costs, tax-benefit policies and work incentives. IZA Discussion Paper No. 1932.

Kabeer, N., Ashwini, D., \& Ragui, A. (2019). Women's access to market opportunities in South Asia and the Middle East \& North Africa: Barriers, opportunities and policy challenges. London: London School of Economics and Political Science, Department of International Development.

Kohler, G., Cali, M., \& Stirbu, M. (2009). Social protection in South Asia. Kathmandu, Nepal: UNICEF.

Lesthaeghe, R. (2010). The unfolding story of the second demographic transition. Population and Development Review, 36 (2), 211-251.

Lewis, J. (1992). Gender and the development of welfare regimes. Journal of European Social Policy, 2, 159-173.

Machado, A., Bilo, C., Veras Soares, F., \& Guerreiro Osorio, R. (2018). Overview of non-contributory social protection programmes in the Middle East and North Africa (MENA) region through a child and equity lens. Braslia and Amman: International Policy Centre for Inclusive Growth United Nations Development Programme and the United Nations Children's Fund.

Martínez Bordón, A., \& Soto de la Rosa, H. (2013). Programas para el cuidado y el desarrollo infantil temprano en los países del sistema de la integración centroamericana (SICA). Comisión Económica para América Latina y el Caribe (LC/MEX/L.1092), México, D.F., Publicación de las Naciones Unidas.

Moghadam, V. M. (2005). Gender and social policy: Family law and women's economic citizenship in the Middle East. International Review of Public Administration, 10(1), 23-44.

Mokomane, Z. (2011). Work-family balance: Overview of policies in developing countries. UN-DESA.

Mokomane, Z. (2012). Anti-poverty family-focused policies in developing countries. UN-DESA.

Moss, P., \& O'Brien, M. (2006). International review of leave policies and related research 2006. UK Department of Trade and Industry Research Series No. 57 (Julio).

Niño-Zarazua, M., Barrientos, A., Hulme, E., \& Hickey, S. (2010). Social protection in sub-Saharan Africa: Will the green shoots blossom? (Working Paper 116). Brooks World Poverty Institute. Available at mpra.ub.uni-muenchen.de/22422.

O'Brien, M. (2012). Work-family balance policies. Division for Social Policy and Development, United Nations Department of Economic and Social Affairs.

OECD. (2011). Doing better for families. OECD.

OECD. (2019a). CO2.2: Child poverty: OECD family database. OECD-Social Policy Division-Directorate of Employment, Labour and Social Affairs. https:// www.oecd.org/els/CO_2_2_Child_Poverty.pdf. 
OECD. (2019b). PF3.2: Enrolment in childcare and pre-schools. OECD Family Database. OECD. http://www.oecd.org/els/soc/PF3_2_Enrolment_childcare_ preschool.pdf (last accessed 30 Mar 2020).

OECD. (2019c). PF3.2: Enrolment in childcare and pre-school. OECD Family Database. OECD_Social Policy Division-Directorate of Employment, Labour and Social Affairs.

OIT, ONU-Mujeres, \& PNUD. (2012). Combatiendo la desigualdad desde lo básico. Piso de protección social e igualdad de género. OIT-ONU-Mujeres-PNUD.

Osorio Gonnet, C. (2019). A comparative analysis of the adoption of conditional cash transfers programs in Latin America. Journal of Comparative Policy Analysis: Research and Practice, 21(4), 385-401.

Pautassi, L., \& Rico, N. (2011). Licencias para el cuidado infantil. Derecho de hijos, padres y madres. Boletin Desafíos Nro 12. Julio. CEPAL-UNICEF.

Ray, R., Gornick, J., \& Schmitt, J. (2008). Parental leave policies in 21 countries. Assessing Generosity and Gender Equality. Washington, DC: Center for Economic and Policy Research.

Rico, N. (2011). Crisis del cuidado y políticas públicas: el momento es ahora. En Rico, N. y Maldonado, C. (coord) Las familias latinoamericanas interrogadas. Hacia la articulación del diagnóstico, la legislación y las políticas. CEPAL.

Rico, N., \& Maldonado, C. (2011). ¿Qué muestra la evolución de los hogares sobre la evolución de las familias en América Latina? In C. Maldonado Valera \& M. N. Rico (Eds.), Las familias latinoamericanas interrogadas. Hacia la articulación del diagnóstico, la legislación y las políticas. CEPAL.

Rossel, C., Filgueira, F., \& Rico, N. (2015). Primera infancia e infancia. In S. Cecchini, F. Filgueira, R. Martínez, \& C. Rossel (Eds.), Instrumentos de protección social: caminos latinoamericanos hacia la universalización. CEPAL.

Roudi-Fahimi, F., \& Mederios Kent, M. (2007). Challenges and opportunities-The population of the Middle East and North Africa (Population Bulletin, Vol. 62, No. 2). Washington, DC: Population Reference Bureau.

Saraceno. (2018). Family policies. In B. Greve (Ed.), Routledge handbook of the welfare state. London: Routledge.

Southern African Social Protection Experts Network. (2016). Conditional cash transfers in Africa: Limitations and potentials. http://www.saspen.org/brief/SASPEN brief-2016-6-Akinola.pdf.

Staab, S. (2010). Social investment policies in Chile and Latin America: Towards equal opportunities for women and children? Journal of Social Policy, 39(4), 607626.

Thévenon, O. (2011). Family policies in OECD countries: A comparative analysis. Population and Development Review, 37(1), 57-87.

Tromben, V., \& Podestá, A. (2019). Las prestaciones familiares públicas en América Latina. Documentos de Proyectos, CEPAL.

United Nations, Department of Economic and Social Affairs. (2015). World Fertility Patterns 2015. Data Booklet (ST/ESA/ SER.A/370). 
van de Kaa, D. (2001). Postmodern fertility preferences: From changing value orientation to new behavior. Population and Development Review, 27(Supplement: Global Fertility Transition), 290-331.

Vegas, E., \& Santibáñez, L. (2010). La promesa del desarrollo en la primera infancia en América Latina y el Caribe. World Bank.

World Bank. (2020a). Fertility rate indicator, World Bank Open Data Bank. https:// data.worldbank.org/indicator/SP.DYN.TFRT.IN.

World Bank. (2020b). Female labor participation indicator, World Bank Open Data Bank. https://data.worldbank.org/indicator/SL.TLF.CACT.FE.ZS?view=chart.

Open Access This chapter is licensed under the terms of the Creative Commons Attribution 4.0 International License (http://creativecommons.org/licenses/by/4.0/), which permits use, sharing, adaptation, distribution and reproduction in any medium or format, as long as you give appropriate credit to the original author(s) and the source, provide a link to the Creative Commons licence and indicate if changes were made.

The images or other third party material in this chapter are included in the chapter's Creative Commons licence, unless indicated otherwise in a credit line to the material. If material is not included in the chapter's Creative Commons licence and your intended use is not permitted by statutory regulation or exceeds the permitted use, you will need to obtain permission directly from the copyright holder.

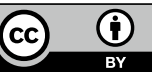

